\title{
YURISDIKSI HUKUM PIDANA DALAM DUNIA MAYA
}

\author{
Oleh : YULIANA SURYA GALIH*)
}

(yuge71@gmail.com)

\begin{abstract}
The development of science and technology has brought changes in the joints of human life, which are increasingly modern. Science and Technology has brought prosperity to humanity, and many benefits have been provided by technological advancements.

Jurisdictional issues relate to the problem of law enforcement, which must be carried out by a State for a crime that has been committed.

Cyber crime is a borderless crime, which can be done anywhere and anytime without recognizing time and space. So to determine jurisdiction in cyber crime is very difficult, and every country has an interest in protecting the sovereignty of its country.
\end{abstract}

Keywords: jurisdiction, cybercrime, cyberspace

\begin{abstract}
Abstrak
Perkembangan ilmu pengetahuan dan teknologi telah membawa perubahan dalam sendi-sendi kehidupan manusia, yang hidup semakin modern. IImu pengetahuan dan teknologi telah membawa kesejahteraan kepada umat manusia, dan banyak manfaat yang telah diberikan oleh kemajuan teknologi.

Masalah yuridiksi berhubungan dengan dengan masalah penegakan hukum, yang harus dilakukan oleh sebuah Negara atas suatu tindak pidana yang telah dilakukan.

Kejahatan cyber merupakan kejahatan yang sifatnya borderless, yang dapat dilakukan dimana saja dan kapan saja tanpa mengenal batas ruang dan waktu. Sehingga untuk menentukan yurisdiksi didalam kejahatan cyber ini sangat sulit, serta setiap Negara mempunyai kepentingan untuk melindungi kedaulatan negaranya.
\end{abstract}

Kata kunci : Yurisdiksi, Cybercrime, Cyberspace

\section{PENDAHULUAN}

Komputer salah satu perangkat hasil teknologi mempunyai keunggulan berupa kecepatan dan ketelitian dalam menyelesaikan pekerjaan sehingga dapat menekan jumlah tenaga kerja, biaya serta memperkecil kemungkinan terjadinya kesalahan. Akibat adanya perangkat komputer ini telah mengakibatkan terjadinya ketergantungan terhadap komputer untuk memainkan peranan menggantikan peran

\footnotetext{
*) Dosen Tetap Fakultas Hukum Universitas Galuh
} 
manusia, bahkan tanpa disadari menjadikan komputer sebagai "dewa" yang mampu melakukan semua pekerjaan yang diperlukan oleh manusia.

Perkembangan lebih lanjut dari teknologi komputer adalah berupa computer network yang kemudian melahirkan suatu ruang komunikasi dan informasi global yang dikenal dengan internet.

Penggunaan teknologi komputer, telekomunikasi, dan informasi tersebut mendorong berkembangnya transaksi melalui internet di dunia. Perusahaanperusahaan berskala dunia semakin banyak memanfaatkan fasilitas internet. Sementara itu tumbuh transaksi-transaksi melalui elektronik atau online dari berbagai sektor, yang kemudian memunculkan istilah e-banking, e-commerce, e-trade, ebusiness, e-retailing, e-government, e-learning dan lain-lain.

Perkembangan Teknologi Informasi dan komunikasi yang semakin cepat dewasa ini, bukan hanya sekedar perkembangan di bidang telekomunikasi dalam bentuk audio visual, di mana seseorang dapat berkomunikasi dengan orang lain melintas batas-batas wilayah negara dan dapat mengetahui bahkan melihat secara langsung suatu peristiwa di belahan bumi lain yang jaraknya ribuan kilo meter.

Kemajuan teknologi tersebut, berakibat pula kepada bentuk-bentuk kejahatan, yang memanfaatken teknologi informasi tersebut. Sehingga timbulnya kejahatan yang dikenal dengan kejahatan dunia maya atau cybercrime.

Cybercrime termasuk jenis kejahatan baru, dan dapat dilakukan di mana saja kapan saja, dengan melintasi batas-batas teroterial suatu negara, sehingga disebut juga transnasional.

Setiap negara mempunyai kedaulatan dan aturan hukum yang harus dihormati oleh negara lain atau dengan kata lain setiap negara mempunyai yurisdiksi.

Berkaitan dengan arti dan makna kedaulatan, Jean Bodin menyatakan bahwa kedaulatan merupakan atribut dan ciri khusus dari suatu negara. Tanpa adanya kedaulatan, maka tidak akan ada yang dinamakan negara (Fred Isjwara, 1996: 89).

Mochtar Kusumaatmadja mengatakan bahwa kedaulatan merupakan suatu sifat atau ciri hakiki dari negara, di mana negara tersebut berdaulat, tetapi mempunyai batas-batasnya, yaitu ruang berlakunya kekuasaan tertinggi ini dibatasi oleh batas-batas wilayah negara itu, di luar wilayahnya negara tersebut tidak lagi memiliki kekuasaan demikian (Mochtar Kusumaatmadja, $2010:$ 7). 
Berbicara mengenai batas suatu negara, hal ini berhubungan dengan masalah yurisdiksi negara tersebut, yaitu mengenai kewenangan negara untuk menegakkan hukum di wilayahnya.

Dalam kaitannya dengan internet yang merupakan suatu dunia tanpa batas, telah menimbulkan masalah tersendiri mengenai yurisdiksi yang akan diterapkan di dunia tanpa batas tersebut.

\section{PEMBAHASAN}

\subsection{Pengertian Cybercrime}

Penggunaan internet yang tidak bertanggungjawab dan bertujuan untuk melakukan kejahatan, telah menimbulkan kerugian bagi orang lain. Kejahatankejahatan yang menggunakan sarana Teknologi Informasi sebagai alat disebut dengan cybercrime. Cybercrime merupakan bentuk kejahatan modern, sebagai akibat dari berkembangnya Ilmu Pengetahuan dan Teknologi.

Cybercrime merupakan bentuk kejahatan yang relatif baru apabila dibandingkan dengan bentuk kejahatan lain yang sifatnya konvensional (street crime). Cybercrime muncul bersamaan dengan lahirnya revolusi Teknologi Informasi. Sebagaimana dikemukakan oleh Ronni R. Nitibaskara bahwa interaksi sosial yang meminimalisir kehadiran secara fisik, merupakan ciri lain revolusi Teknologi Informasi. Dengan interaksi semacam ini, penyimpangan hubungan sosial yang berupa kejahatan (cyber), akan menyesuaikan bentuknya dengan karakter baru tersebut" (repo.unsrat.ac.id).

Istilah cybercrime saat ini merujuk pada suatu tindakan kejahatan yang berhubungan dengan dunia maya (cyberspace) dan tindakan kejahatan yang menggunakan komputer. Ada ahli yang menyamakan antara tindak kejahatan cyber (cybercrime) dengan tindak kejahatan komputer, dan ada ahli yang membedakan di antara keduanya. Meskipun belum ada kesepahaman mengenai definisi kejahatan Teknologi Informasi, namun ada kesamaan pengertian universal mengenai kejahatan komputer ( Dikdik M. Arief Mansur dan Elisatris Gultom, 2005 : 7).

Terminologi cybercrime sebenarnya hendak menunjukan bahwa kejahatan tersebut berada dalam ranah cyberspace. Istilah cyberspace sendiri pada awalnya muncul berasal dari William Gibson dalam novel fantasi ilmiahnya yang berjudul Neuromancer yang terbit pada tahun 1984. Gibson menggunakan kata cyberspace untuk menggambarkan halusinasi bersama yang dialami setiap hari oleh milyaran 
operator resmi di setiap negara dan sebuah kompleksitas yang amat rumit, berkasberkas cahaya yang bertebaran di alam pikiran. Jadi, bila konsisten dengan pemahaman tersebut istilah yang lebih tepat untuk menyebutkan kejahatan di alam maya adalah cybercpace crime (Al. Wisnubroto, $2010: 3$ ).

Pengertian cyberspace tidak terbatas pada dunia yang tercipta ketika terjadi hubungan melalui internet. Bruce Sterling mendefinisikan cyberspace sebagai the place where a telephone conversation appears to occur (Bruce Sterling,1990). Aktivitas yang potensial untuk dilakukan di cyberspace tidak dapat diperkirakan secara pasti mengingat kemajuan Teknologi Informasi yang sangat cepat dan mungkin sulit diprediksi. Saat ini ada beberapa aktifitas yang sudah dilakukan di cyberspace seperti Commercial On-line Services, Bullelin Board System, Conferencing Systems, Internet Relay Chat, Usenet, e-mail list, dan entertainment. Sejumlah aktifitas tersebut mudah dapat dipahami oleh masyarakat kebanyakan sebagai aktivitas yang dilakukan lewat internet. Internet juga sering disebut sebagai a network of net works. Karakteristik seperti ini kemudian ada juga yang menyebut cyberspace dengan istilah virtual community (masyarakat maya) atau virtual world (dunia maya).

Cybercrime merupakan kejahatan bentuk baru dan maju yang bersifat transnasional dan tanpa batas (borderless) sehingga tidak mengenal lagi batas-batas yurisdiksi suatu negara, oleh karena itu dunia internasional terus melakukan berbagai macam langkah-langkah untuk menekan dan mencegah terjadinya kejahatan cyber ini.

\subsection{Pengertian Yurisdiksi}

Kata "yurisdiksi" sendiri dalam bahasa Indonesia berasal dari bahasa Inggris "jurisdiction". "Jurisdiction" sendiri berasal dari bahasa Latin "yurisdictio", yang terdiri atas dua suku kata, yuris yang berarti kepunyaan menurut hukum, dan diction yang berarti ucapan, sabda, sebutan, firman. Jadi, dapat disimpulkan yurisdiksi berarti :

a. Kepunyaan seperti yang ditentukan oleh hukum.

b. Hak menurut hukum.

c. Kekuasaan menurut hukum.

d. Kewenanagan menurut hukum (repository.usu.ac.id/bitstream). 
Yurisdiksi merupakan cerminan dari prinsip dasar kedaulatan negara, kedaulatan suatu negara tidak akan diakui apabila negara tersebut tidak memiliki jurisdiksi (Mirza Satria Buana, 2007 : 56).

Persamaan derajat setiap negara di mana setiap negara yang merdeka dan berdaulat tidak bisa memiliki jurisdiksi (wewenang) terhadap pihak lainnya atau negara lain (equal states don't have jurisdiction over each other) (Mirza Satria Buana, 2007 : 57), dan prinsip tidak turut campur negara terhadap urusan domestik negara lain. Prinsip-prinsip tersebut tersirat dari prinsip hukum "par in parem non habet imperium".

Menurut Hans Kelsen, prinsip hukum "par in parem non habet imperium" ini memiliki beberapa pengertian. Pertama, suatu negara tidak dapat melaksanakan jurisdiksi melalui pengadilannya terhadap tindakan-tindakan negara lain, kecuali negara tersebut menyetujuinya. Kedua, suatu pengadilan yang dibentuk berdasarkan perjanjian internasional tidak dapat mengadili tindakan suatu negara yang bukan merupakan anggota atau peserta dari perjanjian internasional tersebut. Ketiga, pengadilan suatu negara tidak berhak mempersoalkan keabsahan tindakan suatu negara lain yang dilaksanakan di dalam wilayah negaranya. (Huala Adolf, 184).

Yurisdiksi dapat digolongkan ke dalam prinsip-prinsip jurisdiksi berikut :

\section{Yurisdiksi Territorial}

Berlakunya undang-undang pidana suatu negara semata-mata digantungkan pada tempat di mana suatu tindak pidana itu telah dilakukan dan tempat tersebut haruslah terletak didalam wilayah negara yang bersangkutan.

Prinsip ini diatur dalam pasal 2 KUHP, yang menyatakan : "Ketentuan pidana dalam perundang-undangan Indonesia diterapkan bagi setiap orang yang melakukan suatu tindak pidana di Indonesia".

Berdasarkan prinsip ini negara dapat menerapkan yurisdiksi nasionalnya terhadap semua orang (baik Warga Negara Indonesia maupun Warga Negara Asing), badan hukum atau semua benda yang ada di dalamnya. prinsip ini diperluas oleh pasal 3 KUHP yang menyatakan : "Ketentuan pidana perundang-undangan Indonesia berlaku bagi setiap orang yang di luar wilayah Indonesia melakukan tindak pidana didalam kendaraan air atau pesawat udara Indonesia".

Dalam prinsip teritorial, yang menjadi titik berat diletakkan pada terjadinya perbuatan di dalam wilayan negara. Siapa yang melakukannya, warganegara atau orang asing tidak menjadi masalah. 
Menurut Hakim Lord Macmillan suatu negara memiliki yurisdiksi terhadap semua orang, benda, perkara-perkara pidana atau perdata dalam batas-batas wilayahnya sebagai pertanda bahwa negara tersebut berdaulat. Pernyataan Lord Macmillan berbunyi demikian :

"It is essebtial attribute ofthe sovereignity, of this realm, as of all sovereign independent states, that it should posses jurisdiction over all persons and things within its territorial limits and in all causes and criminal arisingwithin these limits." ( Huala Adolf, 189).

\section{Yurisdiksi Personal}

Menurut prinsip yurisdiksi personal, suatu negara dapat mengadili warga negaranya karena kejahatan yang dilakukannya di mana pun juga. Sebaliknya, adalah kewajiban negara untuk memberikan perlindungan diplomatik kepada warga negaranya di luar negeri. Ketentuan ini telah diterima secara universal.

\section{a. Prinsip Nasional Aktif}

Lamintang (1990:92) berpendapat, menurut azas ini, undang-undang pidana suatu negara tetap dapat diberlakukan terhadap warga negaranya di manapun mereka ini berada, bahkan juga seandainya mereka itu berada di luar negeri. Azas ini dianut oleh undang-undang pidana Indonesia seperti yang tercantum didalam pasal 5 KUHP, yang menyatakan : "Hukum Pidana Indonesia berlaku bagi setiap warga negara Indonesia yang melakukan tindak pidana baik di dalam maupun di luar negeri".

Prinsip ini menyatakan bahwa negara dapat memberlakukan yurisdiksi nasionalnya terhadap warga negeranya yang melakukan tindak pidana sekalipun tindak pidana itu dilakukan dalam yurisdiksi negara lain.

\section{b. Prinsip Nasional Pasif}

Prinsip ini membenarkan negara untuk menjalankan yurisdiksi apabila seorang warga negaranya menderita kerugian. Dasar pembenaran prinsip nasionalitas ini adalah bahwa setiap negara berhak melindungi warga negaranya di luar negeri, dan apabila negara teritorial di mana tindak pidana itu terjadi tidak menghukum orang yang menyebabkan kerugian tersebut, maka negara asal korban berwenang menghukum tindak pidana itu, apabila orang itu berada di wilayahnya. 


\section{Yurisdiksi Perlindungan}

Azas melindungi diatur didalam pasal 4 KUHP yang memberlakukan perundang-undangan Pidana Indonesia bagi setiap orang yang di luar wilayah Negara Indonesia melakukan perbuatan yang merugikan kepentingan nasional, yaitu :

1. Kejahatan terhadap keamanan Negara dan kejahatan terhadap martabat/ kehormatan Presiden Republik Indonesia dan Wakil Presiden Republik Indonesia (pasal 4 ke-1 KUHP).

2. Kejahatan mengenai pemalsuan mata uang atau uang kertas Indonesia atau segel/ materai dan merek yang digunakan oleh pemerintah Indonesia (pasal 4 ke-2 KUHP).

3. Kejahatan mengenai pemalsuan surat-surat hutang atau sertifkat-sertifikat hutang yang dikeluarkan oleh Negara Indonesia atau bagian-bagiannya (pasal 4 ke-3 KUHP).

4. Kejahatan mengenai pembajakan kapal laut Indonesia dan pembajakan pesawat udara Indonesia (pasal 4 ke-4 KUHP).

Azas Perlindungan memuat prinsip bahwa peraturan Hukum Pidana Indonesia berlaku terhadap tindak pidana yang menyerang kepentingan hukum Negara Indonesia, baik dilakukan oleh Warga Negara Indonesia atau bukan yang dilakukan di luar Indonesia, jika tindak pidana tersebut mengancam keamanan dan keutuhan negara yang bersangkutan.

\section{Yurisdiksi Universal}

Yurisdiks universal atau persamaan, setiap negara mempunyai kewajiban untuk turut serta dalam usaha memelihara keamanan dan ketertiban dunia negaranegara lain. Walaupun dengan sangat terbatas, azas ini juga dianut didalam undangundang pidana Indonesia, yaitu seperti yang terdapat antara lain dalam pasal 438 dan $444 \mathrm{KUHP}$, yang mengancam dengan hukuman-hukuman terhadap siapa saja yang telah bersalah melakukan pembajakan di laut dengan segala akibat yang mungkin dapat timbul karena perbuatan tersebut.

Yurisdiksi universal ini juga terdapat dalam ketentuan-ketentuan Pidana sebagaimana diatur didalam pasal 4 angka 2 dan pasal 4 angka 4, sepanjang kepentingan-kepentingan negara lain juga dilindungi oleh ketentuan-ketentuan Pidana tersebut. 


\subsection{YURISDIKSI DALAM CYBERCRIME}

Banyak permasalahan hukum yang muncul ketika kejahatan di dunia maya (cybercrime) dapat diungkap oleh aparat penegak hukum, khususnya apabila dalam kejahatan tersebut terkait unsur-unsur asing, salah satu permasalahan hukum utama yang muncul bersamaan dengan terungkapnya kejahatan tersebut adalah masalah yurisdiksi hukum pidana suatu negara, termasuk kewenangan negara untuk menangkap, menahan, menuntut dan mengadili tersangka.

Yurisdiksi merupakan hal yang sangat crucial sekaligus kompleks khususnya berkenaan dengan pengungkapan kejahatan-kejahatan didunia maya yang bersifat internasional (international cybercrime). Dengan adanya kepastian yurisdiksi maka suatu negara memperoleh pengakuan dan kedaulatan penuh untuk berbagai aturan dan kebijakannya secara penuh. Kekuasaan demikian harus diharomati pula oleh setiap negara lainnya sebagaimana kekuasaan yang dimiliki oleh negara-negara lain. (Yudha Bhakti Ardhiwisastra,1999:14)

Black Laws Dictionary, menyebutkan jurisdiction is (Henry Campbell Black, 1979:766) :

a. The word is a term of large and comprehensive import, and embraces every ind of judicial action.

$b$. It is the uthority by which couerts and judicial officers take cognizance of end decide cases.

c. The legal right by which judges exercise their autority.

d. Its exists when courts has cognizance of class o cases involved,proper parties are presents, and point to be decide is within powers of courts.

e. Power and authority of courts to har and determine a juicial procceding.

$f$. The right of power of a courts to adjudicate concerning the subject matter in a given case.

Dalam Encyclopedia of International Law definisi jurisdiksi adalah :

Juisdiction is the authority of the state to affect legal interests. International Law defines the jurisdiction a state may exercise over persons or property with connection that a beyond that state's own territory. (Encyclopedia International Law,136)

Yurisdiksi adalah kekuasaan atau kompetensi hukum negara terhadap orang, benda atau peristiwa (hukum) atau berkaitan dengan masalah berlakunya hukum 
disuatu wilayah/ kedaulatan negara yang merdeka yang terdiri atas wilayah darat, laut dan wilayah udara yang ada di atas wilayah suatu negara.

Masalah jurisdiksi dan teori-teori tentang jurisdiksi banyak mengalami perubahan didalam penerapannya, harus diakui bahwa untuk menerapkan jurisdiksi yang tepat dalam kejahatan-kejahatan di dunia maya (cybercrime) bukanlah merupakan pekerjaan yang mudah, karena jenis kejahatannya bersifat transnasional, sehingga banyak bersinggungan dengan kedaulatan negara lain khususnya dengan sistim hukum negara lain.

Yurisdiksi suatu negara dalam pengertian konvensional, telah diakui oleh hukum Internasional yang berdasarkan pada batas-batas geografis, sementara komunitas multimedia bersifat internasional, multi yurisdiksi dan tanpa batas (borderless), sehingga sampai saat ini belum dapat ditentukan secara pasti bagaimana yurisdiksi suatu negara atau suatu forum yang berlaku terhadap komunikasi multimedia sebagai pemanfaatan Teknologi Informasi.

Jurisdiksi pada cyber pada hakekatnya berkaitan dengan masalah kekuasaan atau kewenangan, yaitu siapa yang berwenang mengatur dunia internet. Mengenai masalah jurisdiksi di dunia internet, ada beberapa pendapat para ahli yang antara lain didasarkan pada prinsip-prinsip jurisdiksi konvensional, namun ada pula yang mengemukakan teori-teori jurisdiksi modern.

Masaki Hamano dalam tulisannya yang berjudul Comparative Study in the Approach to Jurisdiction in Cyber space. (Barda Nawawi Arief, 246) pada prinsipprinsip tradisional atau jurisdiksi tradisional yang berkaitan dengan batas-batas kewenangan negara dalam tiga bidang penegakan hukum, yaitu :

1. Yurisdiksi legislatif (Jurisdiction to prescribe) adalah wewenang negara untuk membuat hukum sesuai dengan masyarakat dan keadaan yang ada. Dalam keterkaitannya dengan internet, muncul pertanyaan ialah negara mana yang berwenang terhadap kegiatan atau orang di dunia cyber? Menimbulkan suatu permasalahan yaitu "choice of law".

2. Yurisdiksi untuk mengadili (Jurisdiciton to adjudicate). Yurisdiksi untuk mengadili didefinisikan sebagai wewenang negara terhadap seseorang untuk melakukan proses pemeriksaan pengadilan, dalam masalah kriminal. Pada yurisdiksi ini, masalah yang muncul adalah "choice of forum". 
3. Yurisdiksi untuk melaksanakan (Jurisdiction to enforce). Yurisdiksi untuk melaksanakan berhubungan dengan wewenang suatu negara untuk melakukan penghukuman terhadap terdakwa sesuai hukum yang berlaku, baik melalui pengadilan atau melalui tindakan non-hukum lainnya (sanksi administratif).

Masaki Hamano membedakan pengertian cyber jurisdiction dari sudut pandang dunia cyber/ virtual dan dari sudut hukum. Dari sudut dunia virtual, cyber jurisdiction sering diartikan sebagai "kekuasaan sistem operator dan para pengguna (users) untuk menetapkan aturan dan melaksanakannya pada masyarakat di ruang cyber/ virtual. Dari sudut hukum, cyber jurisdiction atau jurisdiction in cyberspace adalah kekuasaan fisik pemerintah dan kewenangan mengadili terhadap pengguna internet atau terhadap aktivitas mereka diruang cyber (physical government's power and court's authority over Netusers or their activity in cyberspace). (www.library.upnvj.ac.id,60).

Darrel Menthe dalam "Jurisdiction In Cyberspace: A Theory of International Spaces" menyebutkan suatu wilayah teritorial yang menggunakan hukum internasional dan disebutnya "international space" (ruang internasional); saat ini ada tiga macam ruang internasional yaitu : Antartica, angkasa luar, dan lautan luas. Dalam dunia cyber, jurisdiksi mengesampingkan masalah konsep untuk pengadilan domestik dan pengadilan asing yang serupa. Tidak seperti jurisdiksi tradisional yang melibatkan dua, atau tiga jurisdiksi yang bertentangan satu sama lain, maka hukum yang dapat diterapkan terhadap homepage adalah hukum secara keseluruhan. (Darrel C. Menthe,1998).

Darrel Menthe juga membedakan tiga jenis jurisdiksi yang diakui secara internasional, yaitu: jurisdiction to prescribe (jurisdiksi legislatif/ jurisdiksi formulatif), jurisdiction to adjudicate (jurisdiksi aplikatif/ jurisdiksi yudikatif), dan jurisdiction to enforce (jurisdiksi eksekutif).

Dalam kegiatan di cyberspace, Darrel Menthe menyatakan bahwa yurisdiksi di cybespace membutuhkan prinsip-prinsip yang jelas yang berakar dari hukum Internasonal, dan hanya melalui prinsip-prinsip yurisdiksi dalam hukum Internasioanl ini Negara-negara dapat dihimbau untuk mengadopsi pemecahan yang sama terhadap pertanyaan mengenai yurisdiksi di internet. (Darrel C. Menthe,1998)

Menthe menunjuk pada beberapa teori yang berlaku di Amerika Serikat, yaitu :

1. The Theory of The Uploader and the Downloader. 
Berdasarkan teori ini, bahwa selama berinteraksi di dunia cyber ada dua hal utama yaitu uploader adalah pihak yang memberikan informasi kedalam cyber space sedangkan downloader adalah pihak yang mengakses informasi. Suatu negara dapat melarang dalam wilayahnya kegiatan uploading dan downloading yang diperkirakan dapat bertentangan dengan kepentingan negara.

2. The Theory of the Law of The Server

Pendekatan lain yang dilakukan adalah dengan memperlakukan server dimana webpages secara fisik berlokasi, yaitu dimana mereka dicatat sebagai data elektronik. Menurut teori ini sebuah web pages yang berlokasi di server pada Stanford University tunduk pada hukum California. Namun teori ini akan sulit digunakan jika uploader berada di dalam yurisdiksi asing.

3. The Theory of International Space.

Menurut teori ini, cyberspace adalah suatu lingkungan hukum yang terpisah dengan hukum konvensional dimana setiap negara memilki kedaulatan yang sama. Dalam kaitan dengan teori ini Menthe mengusulkan agar cyberspace menjadi fourth space. Dalam Hukum internasional dikenal ruang dimensi keempat yaitu ruang angkasa, bahwa kegiatan di cyberspace dianalogikan sebagai kegiatan ruang angkasa, semua kegiatan disana diatur secara bersama oleh negara-negara.

David R. Johnson dan David G.Post dalam artikel berjudul "And How Should the Internet Be Governed?" mengemukakan 4 model, yaitu :

1. Pelaksanaan kontrol dilakukan oleh badan-badan pengadilan yang saat ini ada (the existing judicial forums)

2. Penguasa Nasional melakukan kesepakatan internasional mengenai "the governance of Cyberspace".

3. Pembentukan suatu organisasi internasional baru (A New International Organization) yang secara khusus menangani masalah-masalah di dunia internet

4. Pemerintah/ pengaturan tersendiri (self-governance) oleh para pengguna internet. (Barda Nawawi Arif, 260) 
Johnson dan Post berpendapat penerapan prinsip-prinsip tradisional dari "Due Process and personal jurisdiction" tidak sesuai dan mengacaukan apabila diterapkan pada cyberspace. Menurutnya, cyberspace harus diperlakukan sebagai suatu ruang yang terpisah dari dunia nyata dengan menerapkan hukum yang berbeda untuk cyberspace (cyberspace should be treated as a separate "space" from the "real world" by applying distinct law to cyberspace). (Barda Nawawi Arif, 261)

Christopher Doran berpendapat bahwa, pandangan Johnson dan Post tidak dapat diterapkanya jurisdiksi personal terhadap para terdakwa internet, bukanlah pandangan yang menonjol/ berpengaruh. Demikian juga dengan pendapat dari Masaki Hamano juga menyatakan ide Johnson dan Post tidak terwujud dalam kenyataan. Menurut Masaki Hamano, sekalipun banyak kasus-kasus hukum yang berhubungan dengan dunia cyber, namun pengadilan-pengadilan di Amerika Serikat telah menerima pendekatan tradisional terjadap sengketa jurisdiksi cyberspace daripada membuat seperangkat peraturan baru yang lengkap mengenai cyberlaw. (Barda Nawawi Arif, 262)

Masalah Yurisdiksi di internet, sulit untuk dapat diselesaikan karena, tidak ada satu Negara yang berhak untuk memutuskan bahwa yurisdiksi di dunia maya (cyberspace). Hal ini muncul karena sulitnya memutuskan dimana wilayah cyberspace itu berada.

Menghadapi masalah yurisdiksi di dunia maya (cyberspace), serta memperhatikan ketentuan-ketentuan dalam convention on cybercrime, barda nawawi mengemukakan prinsip-prinsip universal dan prinsip ubikuitas (the principle of ubiquity), untuk memecahkan masalah yurisdiksi dunia maya (cyberspace). (Barda Nawawi Arif, 262)

Prinsip ubikuitas adalah prinsip yang menyatakan bahwa delik-delik yang dilakukan/ terjadi sebagian wilayah teritorial negara dan sebagian di luar teritorial suatu negara, harus dapat dibawa ke dalam jurisdiksi setiap negara yang terkait. Prinsip ubikuitas ini pernah direkomendasikan dalam "International Meeting of Experts on The Use of Criminal Sanction in The Protection of Environment, Internationally, Domestic and Regionally di Portland, Oregon, Amerika Serikat, tanggal 19-23 Maret 1994. (Barda Nawawi Arif, 262) Dalam pendapat beberapa sarjana sebagaimana telah disebut diatas, belum ada yang menyebut tentang perlunya dikaji ulang untuk menggunakan prinsip ubikuitas, apabila memang dipandang tepat. 
Menurut Soedarto, untuk menuntut seseorang di depan pengadilan perihal tindak pidana, maka harus pasti tentang waktu dan tempat terjadinya tindak pidana. Ketentuan tentang waktu diperlukan untuk menentukan apakah undang-undang yang bersangkutan dapat diterapkan terhadap tindak pidana itu, sedang ketentuan tentang tempat diperlukan untuk menetapkan apakah undang-undang pidana Indonesia dapat diperlakukan dan juga pengadilan mana yang berkompeten untuk mengadili orang yang melakukan tindak pidana tersebut (kompetensi relatif. (Soedarto,1991: 36-37).

Didalam menentukan locus delicti, maka oleh IImu Hukum Pidana dan yursprudensi telah dibuat 3 macam teori, yaitu :

\section{a. Teori Perbuatan Materiil (leer van de lichamelijke daad)}

Menurut teori ini, maka yang menjadi locus delicti ialah tempat dimana pembuat melakukan segala yang kemudian dapat mengakibatkan delik yang bersangkutan. Pendapat ini dianut oleh Hoge Raad dalam Keputusannya tertanggal 16 Oktober 1899, W. Nr. 7347, dalam Van Bemmelen Burgersdijk, Arresten Strafrecht, Nr. 14, hlm. 40. (E. Utrecht,1986: 234)

Dengan keputusan ini Hoge Raad menerima teori perbuatan materiil. Locus delicti adalah tempat dimana perbuatan yang perlu ada supaya delik dapat terjadi dilakukan oleh pembuat. Waktu dan tempat delik harus sama dan hanya waktu ketika perbuatan materiil diadakan dapat menjadi waktu delik. (Utrecht, 235)

\section{b. Teori alat yang dipergunakan (instrumen)}

Teori perbuatan materiil ternyata tidak dapat menyelesaikan kesulitankesulitan yang dimbul, maka lahirkan teori alat yang dipergunakan, teori ini dianut oleh Hoge Raad dalam Keputusannya, tertanggal 6 April 1915, Nj. 1915 hal, 427, dalam Van Bemmelen Burgersdijk, Nr. 15, hlm. 43 (Utrecht, 236)

Menurut teori alat yang dipergunakan, maka delik dilakukan di tempat dimana alat yang dipergunakan itu menyelesaikannya.

\section{c. Teori Akibat}

Didalam menyelesaikan masalah dalam hal menentukan dimanakah locus delicti itu terjadi, teori alat yang dipergunakanpun tidak dapat menyelesaikan masalah, hal ini bisa terjadi karena tidak ada alat yang dipergunakan, maka IImu Hukum Pdana membuat tambahan, yang merupakan suatu tingkatan lebih lanjut (verder gaande trap), tambahan itu adalah teori akibat. 
Menurut teori akibat maka tempat akibat (plaats van het gevolg) menjadi locus delicti. (Utrecht, 238)

Bahwa perdapatan mengenai yurisdiksi dunia maya (cyberspace), sejauh ini belum ada pendapat yang dapat dijadikan acuan, untuk menentukan yurisdiksi didalam dunia maya tersebut, karena memang kejahatan di dunia maya yang bersifat transnasional sehingga setiap Negara mempunyai kepentingan terhadap yurisdiksinya.

Suatu kejahatan di dunia maya atau cybercrime juga harus memperhatikan seberapa besar kerugian yang diakibatkan oleh pelaku kejahatan cyber itu sendiri. Kejahatan-kejahatan yang berdampak cukup luas yang menyangkut masalah kedaulatan, keamanan dan kemanusiaan yang harus lebih diperhatikan, sehingga perlu adanya kerjasama internasional yang harus dilakukan oleh semua Negara untuk menanggulanginya, sehingga dari beberapa pendapat para ahli hukum dapat ditentukan yurisdiksi negara mana yang berwenang untuk mengadili kasus tersebut.

\section{KESIMPULAN}

Perkembangan Teknologi Informasi membawa dampak pula terhadap timbulnya kejahatan-kejahatan yang menggunakan teknologi tersebut. Cybercrime merupakan bentuk kejahatan yang menggunakan internet sebagai sarana untuk melakukan kejahatan tersebut.

Cybercrime sebagai salah satu bentuk kejahatan transnasional, telah membawa persoalan-persoalan kepada masalah yurisdiksi. Yurisdiksi adalah kewenangan suatu negara untuk mengadili suatu perkara, karena setiap negara mempunyai yurisdiksi masing-masing yang harus dihormati oleh setiap negara. Sedangkan cybercrime yang berada didunia maya, sehingga yurisdiksi Negara mana yang berhak untuk mengadili atas kejahatan cyber tersebut, sedangkan setiap Negara mempunyai kepentingan. 


\section{DAFTAR PUSTAKA}

\section{Buku-Buku}

Arsyad Sanusi, M, Hukum dan Teknologi Informasi, Tim Kemas Buku, Jakarta, 2005.

Bhakti Ardhiwisastra, Yudha, Imunitas Kedaulan Negara di Forum Pengadilan Asing, Alumni, Bandung, 1999.

Teori Hukum Pembuktian Pidana dan Perdata, Citra Aditya Bakti, Bandung, 2012.

Isjwara Fred, Pengantar IImu Politik, Binacipta, Bandung, 1996.

Lamintang, P.A.F. Dasar-dasar Hukum Pidana Indonesia, Sinar Baru, Bandung, 1990.

M. Arif Mansur, Didik dan Alisatris Gultom, Cyber Law-Aspek Hukum Teknologi Informasi, Refika Aditama, Bandung, 2005

Makarim, Edmon, Kompilasi Hukum Telematika, PT. Raya Grafindo Persada, Jakarta.

Nawawi Arief, Barda, Sari kuliah Perbandingan Hukum Pidana, Raja Grafindo Persada, Jakarta, 2002.

Kapita Selekta Hukum Pidana, Citra Aditya Bhakti, Bandung, 2003.

Raharjo, Agus, Cybercrime, Pemahaman Dan Upaya Pencegahan Kejahatan Berteknologi, Citra Aditya Bahkti, Bandung, 2002.

Sjahputra, Iman, Problematika Hukum Internet Indonesia, PT. Prenhallindo, Jakarta.

Soedarto, Hukum Pidana I, Yayasan Sudarto, Semarang, 1990

Sulistyo Sutanto, Hermawan dan Tjuk Sugiarto, Cybercrime-Motif dan Penindakan, Pensil 324, Jakarta.

Utrecht, E, Rangkaian Sari Kuliah Hukum Pidana I, Pustaka Tinta Mas, Surabaya, 1986.

Wahid, Abdul dan Mohammad Labib, Kejahatan mayaantara (cyber crime), PT. Rafika Aditama, Bandung, 2005.

Wisnubroto, Al, Strategi Penanggulangan Kejahatan Telematika, Atma Jaya, Yogyakarta, 2010.

\section{Perundang-undangan :}

1. Kitab Undang-undang Hukum Pidana (KUHP) 
2. Undang-undang No 11 tahun Tahun 2008 tentang Informasi dan Transaksi Elektronik.

\section{e-book/ internet}

Darrel C. Menthe, Jurisdiction In Cyberspace: A Theory of International Spaces, 4 Mich. Telecomm. Tech. L. Rev. 69 (1998) available at <http://www.mttlr.org/ volfour/menthe.pdf.

Lucian, Vasiu \&loana Vasiu. Dissecting Computer Fraud: From Definitional Issues to a Taxonomy, Proceedings of the 37th Hawaii International Conference on System Sciences, 2004.

Seri Perjanjian Eropa No. 185, Konvensi Tentang Tindak Pidana Telematika, Budapest, 23.XI.2001 .

Susan W. Brener, Cyber crime Metrics: Old Wine, New Bottles?, Virginia Journal Law \&Technology, Universitu of Verginia, Fall 2004, vol.9. No. 13.

UNESCO, The Internasional Demension of Cyberspace Law, England, Ashgate Publishing, Ltd, 2000.

United Nations A/CONF.187/10, Tenth United Nations Conggress on The Prevebtion of Crime and the Treatment of Offender, Vienna, 10-17 April 2000. 